\title{
INSTAGRAM STORIES FROM THE PERSPECTIVE OF NARRATIVE TRANSPORTATION THEORY
}

\author{
Murat SEYFI \\ Gaziosmanpaşa University , Turkey \\ seyfi.murat@gmail.com \\ Ayda Uzunçarşılı SOYDAŞ \\ Marmara University, Turkey \\ aydaus@gmail.com
}

\begin{abstract}
Stories, which have been important parts of social life for centuries, are narratives that keep social memory alive. With developments in communication technology, many of its constituents like its format, transfer speed, environments and size have changed and developed. Especially the narratives that have emerged through the effects of social media and have started to form a new century's new stories. This study analyzes that how the stories that are shared on Instagram create a sustainable story from the perspective of narrative transportation theory. In the research part of the study, a multidimensional analysis applies netnography and content analysis research techniques.
\end{abstract}

Keywords: Instagram, Narrative, Netnography, Storytelling, Memory

\section{ANLATI AKTARIM TEORISI PERSPEKTIFINDE INSTAGRAM HİKAYELERİ}

ÖZ

Hikayeler yüzyıllardan beri toplumsal yaşamın önemli bir parçası olmuş, toplumsal belleği canlı tutan anlatılardır. İletişim teknolojilerindeki gelişmeler ile birlikte hikayelerin formatları, aktarım hızları, mekanları, boyutları gibi birçok bileşenide değişmiş ve gelişmiştir. Özellikle sosyal medyanın etkileri ile ortaya çıkan anlatılar yeni yüzyılın yeni hikayelerini oluşturmaya başlamışıı. Bu çalışmada anlatı aktarım teorisi perspektifinde Instagram üzerinden paylaşılan anlatıların nasıl sürdürülebilir bir hikaye yarattığ 1 incelenmiştir. Çalışmanın araştırma kısmında netnografi ve içerik çözümleme araştırma teknikleri kullanılarak çok boyutlu bir çözümleme yapılmıştır..

\section{Anahtar kelimeler: Instagram, Anlatı, Netnografi, Storytelling, Hafiza}

\section{INTRODUCTION}

Stories have always played a part in people's lives throughout the history of humanity, and have provided societies' sustainability through the transportation of cultural codes. Rapidly changing and developing communication technologies have created new "narrative" forms with the effect of globalization. One of these communication means which, unlike the printing press, drags people into tribal life and transforms people into digital tribesmen, is Instagram. Instagram has become an increasingly popularized visual messaging medium in the digital narrative world, where 40 million photos are uploaded daily and 1000 comments are made per second. In 2013, Instagram expanded its influence and reach by providing video uploading (Vaynerchuk, 2013:26-50). Instagram created a new potential narrative language of photos between different cultures and countries. It developed a natural facilitative language which enables people to tell about themselves or understand one another. Thanks to this, stories and storytellers have developed rapidly and now are able to address wider audiences.

In the literature review, the concepts of culture and digital storytelling are analyzed. The research model of the study is formed by combining netnography and content analysis research techniques. Within this framework, the official Instagram account of the Canadian Cancer Society has been 
analyzed since its establishment day on 15.05.2015 considering cultural components, and the story that emerged from here is also analyzed.

\section{THE CONCEPT OF NARRATIVE}

Narratology, basically, can be described as the analysis of the narrative from a stylistic aspect. This term became widespread in 1970's due to work Geral Prince, Gerard Genette, Mieke Bal and other structuralist critics. The concept of narrative, which is the base for narratology, is the meaningful representation of events which are related to each other in a timewise and causal manner by using different instruments. This reveals that the concept of narrative has a potential ambiguity. In the narrow sense, narrative is a linguistic phenomenon, an illocution by excluding all other things. In other words, with oral and written narrative, it restricts its analysis area to literary types such as story, saga, poetry, novel and anecdote. The wider structure of narrative is defined as a work "which has a storyline" from aspect of Aristotelianism (Onegai, Angel \& Landa, 2002:9-12). With its narrow and wider extents, narrative is a base for many sciences of art and gains new aspects according to its environment (Ong, 2013:165). Narrative is a whole. By coming together with its constituents it gains new dimensions and aspects. Events and entities are single and independent; however, narrative items are successive and compound. Besides, events in a narrative do not occur accidentally, instead they are linked to each other and have a mutual interaction between them (Chatman, 2008:13-23). There is a deep relationship between the concept of narrative and time. Time only transfers into human time when it is not included in the aspect of narrative; on the contrary, in order for narrative to become meaningful it has to demonstrate characteristics of timewise experiences. It can be explained; "Time becomes typical human time to the extent that it is included according to a narration (narrative) type, and thus narrative retrieves its meaning since it is a condition of timewise existence." (Ricceur, 2007:108). Narrations are made up of events, and only if there is an event transportation, there can be a narration (K1lanç, 2013:40). Narrative includes everything that offers or creates a narration. Whether it is by means of a text, a performance, a picture, a compilation of all these, they are all narratives. Therefore, novels, movies, comics are all narratives (Jann, 2012:44). With the narratives- becoming stories, we have the chance to deliberately evaluate our undeliberately made choices, potential emotions and inference. In other words, stories and narratives integrate audience into the process by changing their state from passive to active, and they give our thoughts the chance to be evaluated in others' minds (Simmons, 2012:25-43).

According to Chatman, narrative consists of two fundamental structures which are content and discourse. Stories which form the content part of the narrative consist of events, entities and cultural codes, and this formation creates the form and core of the content. On the other hand, the discourse part of the narrative consists of the structure of narrative transportation and manifestation. This formation also creates the form and core of the expression. Considering the fact that discourse of the narratives which spread over Instagram consists of photos and short dialogues, the structure of the narrative transportation is revealed and thus, the core of the story is available (Chatman, 2008:23). Transportation applications have a vital role in the organic structure of the narrative both mentally and emotionally. In particular, if this transportation is made by means of mass media applications, it will have a more important role. Looking at the studies, it is observed that this method is used in mass media applications directly effects people's beliefs, attitudes and behaviors (Green and Clarck, 2013:477-484).

Many studies have been conducted to analyze the relationship between stories and persuasion. Especially, some researchers link stories to persuasion through narrative transportation theory. According to Gerrig, "It is assumed that individuals are transported to a world where aesthetic based expression process is used rather than paradigm based analytical process." This expression takes places as a distinct mental process where listeners, audience or readers are fascinated by the place, characters and events of the story and develop potential relationships with them. He demonstrated that in this process expression can have an effect on real world attitudes and behaviors, and also claimed that during the expression process individuals lose contact with some of the characteristics of the real world (Gerrig, 1993:10-11). 
Narrative Transportation Theory provides a basis for researchers to analyze the mental processes in persuasion processes of those the listening stories. It deals with story, apart from explanations, as a special form of process like dual-process models. World facts are the base for story process, and detailing includes piece by piece evaluation of asserted thoughts against formerly known facts. Heuristic process generally relies on contextual cues about individuals' attitudes towards consumption according to story or superficial rules. Actually, all the constituents of a story function as a road map which is intended to create short cuts/heuristic methods to use in future or to change them (cited by, Gilliam, 2011:18-20). Narration can substantially affect individuals' or societies' buying behaviors in product or brand advertising, and has a vital function in understanding and analyzing target markets for companies (Kılanç, 2013:46).

Therefore, narrative creates dynamic patterns between past and future, and integrates mental images which it pictures imaginary situations by uniting possible outcomes. This causes motivation related to actualization possibility of pictured events, which will create a basis for behaviour change, and even leads to new attitudes and behaviors. Thus, sustainable stories take part in the persuasion process of audience by creating sustainable behavior change. Besides, by creating this mechanism by means of social media, interaction between audience and social network can take place, and constantly, the audience plays its roles actively in development and narration of the story.

\section{THE CONCEPT OF CULTURE}

Culture has been defined many times so far, and because of so many definitions it is thought that it cannot be defined. In fact, defining culture is not difficult, the difficult thing is people's agreement on a single definition. It is clear that the origin of the word is colere or culture from Latin. The word culture is first explained by Voltaire by relating its meaning to the development of human mind. The concept of culture has become an interdisciplinary study area. The definitions of culture as an individual and social phenomenon can be summarized as (Güvenç, 2005:96):

- Culture in the field of science is: Civilization.

- Culture in the humane field is: The output of education process.

- Culture in the aesthetic field is: Fine arts.

- Culture in the material and biologic field is: Production, agriculture, crop, reproduction and cultivation.

In its most general and objective definition, "Culture is all the creations of humans. Culture, as a whole, can be divided only with the aim of analysis. All the tools and materials created by humans belong to material culture, and all the senses, values, rules belong to non-material culture." (Kongar, 1999:19). The most basic definition according to Taylor is: "Culture or civilisation is a complicated whole which includes all the knowledge, beliefs, art, rules, customs and traditions and habits which belongs to humankind that is a part of a society."(Cited by: Moore, 2000:17).

\section{Storytelling Elements from the Cultural Perspective}

From cultural perspective, story is a subject that has been studied on for many years. Stories that enabled cultures to become distinct have helped emotions, moral principles, cultural values to be handed down from generation to generation. Besides, stories have a key role in explaining organizational culture. Within this context, we can say that rituals, symbols, heroes and values make up the basis of stories from the cultural perspective (Gabriel, 2000:88-89).

\section{Rituals:}

Rituals play an important part in determining social roles and status. Ritual, from past to present, is a social phenomenon which is sustained orally and practically with social participation, and expressed by standard rhythmical movements and a symbolic language. Ritual both removes to search for searching new motions with each new event and provides fidelity to the past with an emotional connection by showing individuals how to act and by offering behavioral patterns which are already at hand. Ritual is a way for people to say what is important and required (Karaman, 2010:235).

\section{Symbols:}


Symbols are used for expressing all the material and non-material elements of a culture. Therefore, they increase and reinforce the feeling of belonging to the culture. Belk1s Temren defines symbols as: "Tangible things and signals that makes things which cannot be perceived by perceivable emotions." Hence, symbols becomes a shared universal language (Koca, 2010:90-91).

\section{Heroes:}

Heroes make up a vital part of stories. The hero bears the viewpoint that the story aims to offer through his personality, and is virtually a guide for audience. There are many hero types but the things that every hero should do are as follows (Maxwell\&Dickman, 2008:76-78):

- Hero should provide sameness with audience. Thus, trust should be developed between the audience and the hero.

- Heroes have their own time and place. Heroes should share their borders with audience.

- Heroes have an important influence power over audience. Thus, the hero to be chosen should have the abilities to offer such surprise influences.

- Heroes do not have to be human all the time. Sometimes an animal, sometimes a robot, sometimes a photograph but all the heroes must be good.

\section{STORIES}

According to some scientists the concept of story turned into a format that is interwoven with the concept of narrative and they are inseparable. According to Haven (2007) story and narrative are quite different. Narrative is based on the description of an event whereas stories have many elements such as heroes, aims, difficulties, and have a structure which has horizontal components (Haven, 2007:79).

Stories are basis for the continuation of human existence. Since stories preserve and hand down cultural codes and the secrets of social rules. Storytelling can be considered as warranty for human existence and sustainability of society (Benjamin, 2006:161). Stories are a shared knowledge and a source of information that is used collectively. In oral culture, knowledge is a social phenomenon rather than an individual learning process or an experience. Therefore, nobody is smarter or less smart than the others. Stories and other narrative types that are told in a society creates a conscience which leads to interaction of the people around an issue. Together, all members of the society access the information. Thus, stories build a potential sharing network between individuals (Sanders, 2010:22).

It is crucial for storytellers to reach their audience. Within this framework, they have these functions (Luecke: 2007:103):

- They contribute to drawing the attention of the audience, and make theme and characters evident

- They simplify and materialize complicated ideas

- They contribute to the creation of strong emotions within the audience

- Even though the complicated details are forgotten, stories stick in the mind of the audience

Storytelling is the style of expression of the story contained in the narrative. Therefore, it is necessary to make some choices about the story. To sum up, it is by whom, with which viewpoint, in what order, with which rhythm and which form the fictional story and its whose theme is told. For example, Pinocchio can be told seriously, sarcastically, in short or long from, from the beginning to the end or from the end to the beginning. Thus, the distinction between fiction and narration removes the ambiguity of the word of narrative (Kiran\&Kiran, 2007:97).

\section{Digital Storytelling}

When we search the roots of the concept of storytelling in order to understand it, we come across concepts like story or tale. Turkish Language Association considers storytelling as "narrative" in its literature dictionary, and it is defined as; "real or imaginary events' in the forms such as novel, story and tale." (www.tdk.gov.tr, 19.04.2015). 
The concept of Digital Storytelling first appeared in 1980 via the center that was established by Atchley. According to him "Digital tools such as image, film and music are used in Storytelling studies." Gacia (2010) defined digital storytelling as vignettes where digital tools are used. Figa (2004) defines digital storytelling as; "usage of voice, music and visual messages according to text in digital environments." (Figa, 2004:34-36). Chung (2007) emphasises that for successful digital storytelling many different digital tools need to be used (cited by:Conrad, 2013:460). According to Armstrong, "digital storytelling is doing information transportation and story transportation by means of media. Digital storytelling is representation of short movies mostly created by personal stories by using digital tools." (Armstrong,2003:11-18 ). Whereas, according to Robin, "Digital storytelling is association of interaction of multimedia devices such as graphics, videos and voices to create a narration about a specific theme." (Robin, 2008:220-228).

There has not been an explicit study of digital storytelling's elements but these elements are defined in stylistic form according to their intended use. Many scientists have tried to determine the elements of digital narratives to make the analysis of digital storytelling easier. Due to the fact that this subject is an interdisciplinary one, and the users appear formally or informally, clear-cut describable elements have not been developed. Paul and Fiebich analyzed digital storytelling's elements in five different titles. They are as follows (cited by:İnceelli, 2005:134-140):

- Media Usage: In media usage, the combination of media appears with the usage of single media, multiple media and multimedia. The graphics, videos, animations, visual effects and, music that are used provide the identification of media type. Flow process appears with the tyepe of sharing like interactive, live, video broadcasting of story.

- Motion: Both the content's and the user's motions are vital in digital storytelling process. Motion of the content can be stable, dynamic and combined. Motion of the user can be passive, active and mutual.

- Relationship: The relationship chain between the story and the audience is defined in this step. This relationship consists of linear, customizing, calculation, processing and adding steps. In the customizing step the audience makes the story personalized. In the calculation step statistics between story and audience are identified. In the processing, the step audience is included into the story by the storyteller. In the adding step, feedback from storytellers is added into the story.

- Context: Context has a major importance in digital storytelling, since it surrounds the story and gives it a meaning. It is possible to give unlimited meanings to stories with the context on social media.

- Communication: The multilayered communication environment that creates digital stories has multiple effects in the process of reaching to the audience. By surpassing normal media practices, this can easily be accomplished on social media. Since this communication chain can take place in many ways like one-to-one, multimedia and many other forms (chat, Twitter messages, forum post etc.), it has many effects.

The digital storyteller's most powerful weapon is transmedia storytelling. Transmedia storytelling has become more efficient with the development of both technology and people's search for new communication methods. It has been used in all the communication channels that are in our lives without our realisation. Jenkins widened its definition with his work named "Seven Principles of Transmedia Storytelling". This list consists of inner stylistic conflict and four individual characteristic pairs. These are Spreadability vs. Drillability, Continuity vs. Multiplicity, Immersion vs. Extractability, Worldbuilding, Seriality, Subjectivity and Performance (Jenkins, 2014).

\section{Place/ Space/ Memory}

According to the Turkish Language Association space is "an object's area in space; breadth" and "basic quality of perceived objects" whereas place is " the location that one is found in" (www.tdk.gov.tr, 2015). When the concept of place is evaluated from the perspective of history of humankind, it can be seen that it is a special concept that holds many potential codes in it beyond "location that one is found in". "Place, in addition to its being a location which is produced, built, 
created, it is also a social environment where social events take place. Place is a pot where history takes place, and is a register where time turns into history." (Alver, 2010:19). Therefore, place and space, beyond their technical structure, have many factors which have sociological and psychological dimensions.

It can be seen that according to their field of usage place and space are sometimes used with the same meaning, and sometimes used in related perceptive meanings. In the press period narrative tools, research of the space is generally made based on the presentation style. In order to comprehend the space, it is required to answer the questions of Where, How, Why (Çetin, 1996:49). However, the concept of space has gained a new dimension through narrative in the digital world, because characters and places started to be created independently from space and time. According to Robins, space is now an electronic environment and it does not have a core (Robins, 1997:76). It would be most logical to evaluate this concept's basis within the context of visual message chains, where place and space are considered within the context of digital stories. Within this framework, place can be defined as the location in which the event takes place. Whereas space can be defined as the "quality" that appears according to the relation of existing things to the which these things are in. For instance, a thought's space can be mentioned but it is not possible to refer to its place. According to Descartes, "Features that are attributed to objects requires space; thus, all the features that are found in the reasonable creature are not different than various ways of thinking. Therefore, we can neither comprehend a form that is not in space, nor a motion that takes place in location which hasn't got space." Similarly, we cannot think about a physical world of the internet but the qualities sprung from this world's outputs have created a huge space (Descartes, 1997:109).

Due to its qualities on the internet, Instagram has created its own unique space. In this space, stories that are created with visual messages have their own visual places and spaces which appear with the qualities that are created by users (audience) in these places. While the place is stable and the only location (Instagram page-internet) for storytellers and audience, space makes up a spatial chain that has thousands of layers. Therefore, Instagram narratives turn into stories with its their symbols, rituals, heroes and values, and this transformation creates a unique memory. The concept of memory that is defined in various ways in different disciplines can be basically defined as the storage, keeping and recalling of information. According to Assman, memory can be divided into two as cultural and communicational memory. Cultural memory focuses on exact events of the past, and it does not stay the same, and mostly emerges with symbolic figures. Real history in cultural memory, first turns into reminiscence then into legend by passing through cultural layers. As for communicational memory, it is about recent past. This kind of memory involves individuals' sharing with other individuals who live in the same period of time. It occurs and disappears in time. It passes to someone else's memory when its owner dies (Assman, 2001:54-55). It can be said that Assman's definition for communicational memory explains memory entities in current social media. On the other hand, before digital communication devices there was a conflict between memory and archives but with digital communication devices and applications like Instagram and similar platforms this conflict has gained a new dimension. According to Huyssen, our way of thinking is constantly changing and is turning into a memory that has no borders. He argues that this occurs because modernity compresses time and place. Our understanding of time and place is evolving so fast with the developments in technology. This caused our memory to produce hypertrophy in its fight with the speed of this change. As we are pushed into this unreliable world our will to slow down will strengthen, and we will turn to our familiar and comfortable memories. Different from our familiar past and present encounters, current future started to change current past in the $80 \mathrm{~s}$ when communication technology development accelerated. (Huyssen, 2003:1-23).

According to Halbwachs, memory creates the socialization process of individuals and it is determined by social elements. As the memory cannot stay the same, its duty is always to "recreate". This explains the organic link between memory society (Sancar, 2010:41-42). Instagram provides the creation of symbols, rituals and heroes with its visual messages, and it creates a memory that has its own dynamics about this creation. This memory makes up its individuals and these individuals' society. 


\section{METHODOLOGY OF THE STUDY}

This study is carried out by applying netnography and content analysis techniques. According to Kozinets, Netnography is "the ethnography of internet or technological network, and is the ethnography that is adapted to our technological modern and social world's complication". Netnography is the adaptation of ethnography to technological networks which is efficiently used by anthropologists. It can be seen that when this technique is compared with ethnography, netnography is more useful in terms of speed and cost. In online groups, netnography reveals information about symbols, secret meanings, reactions, attitudes and behaviours of groups. Netnography technique consists of five steps which are: introduction, data collection analysis, reliable interpretation, ethical research and member check (Varnal1, 2013:17-35). The other technique that is used in this study is content analysis. Due to the fact that the study is being applied to a field that has dense photographic instruments like Instagram, the study is supported with a second research technique, content analysis, that covers the field of semiotics. Content analysis research projects have a common purpose: to interpret content based on elements which are observed and described in messages. Content analysis is a systematic, quantitative and objective technique that is used to describe behavior and interpret content (Bilgin, 2006:1-2). A research practice that is a mix of these two techniques is executed in this study. Before beginning this study, questions (hypothesis) are determined which will direct this study based on netnography. These are;

- Is the Canadian Cancer Society using Instagram as an instrument of narrative transportation?

- Are there storytellers of the Canadian Cancer Society?

- Is the Canadian Cancer Society utilising transmedia applications?

- What are the elements of Instagram narratives?

- What are the effects of heroes, symbols, rituals and values of Instagram narratives on creation of both the audience and the story?

- Do the stories on Instagram consist of only one photo or photos and videos that support one another in different times?

- Do the stories on Instagram have a multi-layered structure that uses memory, space and place?

- Do the narratives on Instagram cause behavioral change in the audience?

\section{Introduction}

Looking at the Instagram page of the Canadian Cancer Society, it is seen that has made 456 posts between 14th December 2015 - 15th May 2015. When these posts are studied in a general framework, it is observed that they consist of both photographic and written narratives in which corporate identity, corporate activities, corporate culture is told. As mentioned in the literature review, narrative is the basis of the story. What is story for narrative? "How" is its discourse? Here, the photos and written posts of the Canadian Cancer Society make up the "what" and "how" part of the narrative.

Every story has a storyteller and audience. The Instagram page of the Canadian Cancer Society created a soft environment where many storytellers and the audience come together. Therefore, the exchange of emotions between the storytellers and the audience becomes easier. A storyteller who adds a new place, time and dimension to story and a transportation process is born like in the Shaman culture where the audience has a voice like the storytellers. This enabled the realization of the 7 principles of transmedia which are Spreadability vs. Drillability, Continuity vs. Multiplicity, Immersion vs. Extractability, Worldbuilding, Seriality, Subjectivity and Performance.

Narratives used by the Canadian Cancer Society on Instagram caused the creation of a strong and lasting story by being supported by symbols, rituals, logos and heroes. Hereby, both the cultural and corporate characteristics are defined more clearly. Looking at the posts that create the stories by being used as a narrative tool, many rituals and heroes appear. Thus, this caused the corporation to create a sustainable narrative instead of compressing them into a single photo. On the other hand, changes of attitude and behavior in the audience are revealed with their interpretation, sharing of the posts and transferring these posts to other channels.

\section{Data Collection}


To achieve this, researcher downloaded on the visual posts from the Canadian Cancer Society's official web page on Instagram, and literary sharings linked to these posts. Despite the fact that each post tells a different story, researcher stipulated that all the stories tell one story, the story of the Canadian Cancer Society by coming together. Data collected from the Instagram page is analyzed with the techniques of content analysis and semiotics.

\section{Findings}

The 456 photographic posts and literary narratives that are created with these posts are analyzed within the scope of this research. Due to the fact that the story is continuing for 3 years and has a deep rooted past, it has a wide perspective. Hence, the story will be analyzed by separating it into sections.

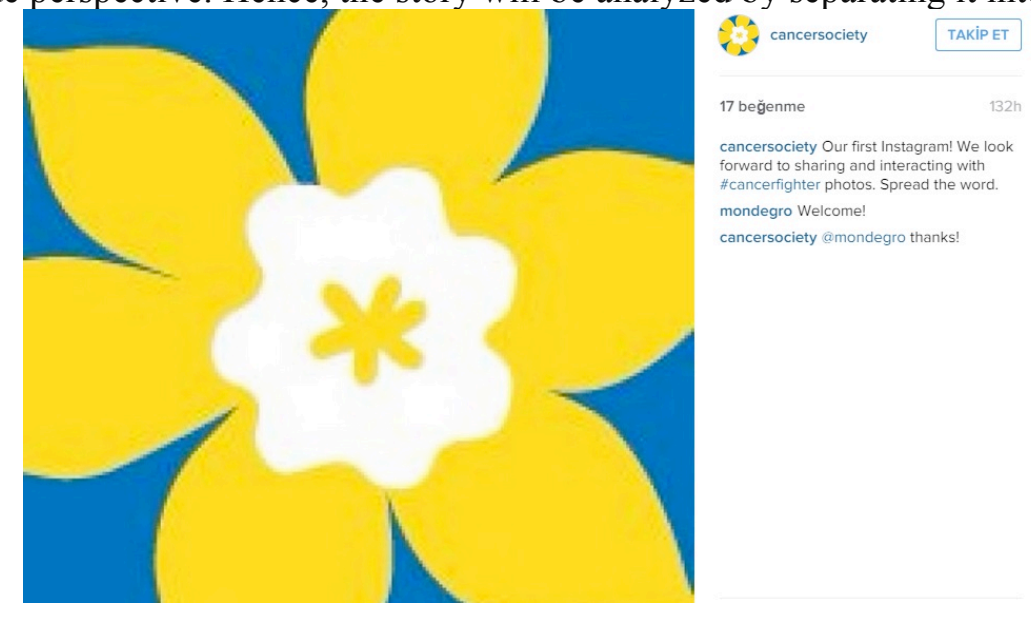

Visual1: Visual Post dated 14 December 2012

This is the starting point of the story. It all begins with the appearance of the hero and the telling of its story through symbols. Rituals, places, mnemonic connotations, heroes that are brought by this starting point makes this story a sustainable narrative.

Visual Post: Logo of the Corporation

Literary Post: Expressions like "Be Voluntary", "Be Strong", "Keep Fighting" are used in this element of narrative that is used in different periods of time.

Ritual: A ritual is created by using the logo of the corporation periodically. Here are the periods:

1 April 2013, 5 April 2013, 9 April 2013, 10 April 2013, 14 April 2013, 15 April 2013, 24 April 2013, 25 April 2013, 27 April 2013, 23 February 2014, 1 April 2014, 3 April 2014, 17 April 2014, 30 April 2014, 14 February 2015, 23 March 2015, 1 April 2015, 8 April 2015, 11 April 2015, 17 April 2015, 20 April 2015, 21 April 2015, 22 April 2015, 1 May 2015

\section{Hero: Canadian Cancer Society}

Evocations over Audience: Definition of corporate structure, corporate culture, corporation's activities, non-governmental organization's influence on Instagram and its being recognized in a new place and time.

Place/ Space/ Memory: Place is internet, space is Instagram world, memory is factors about corporate identity. 


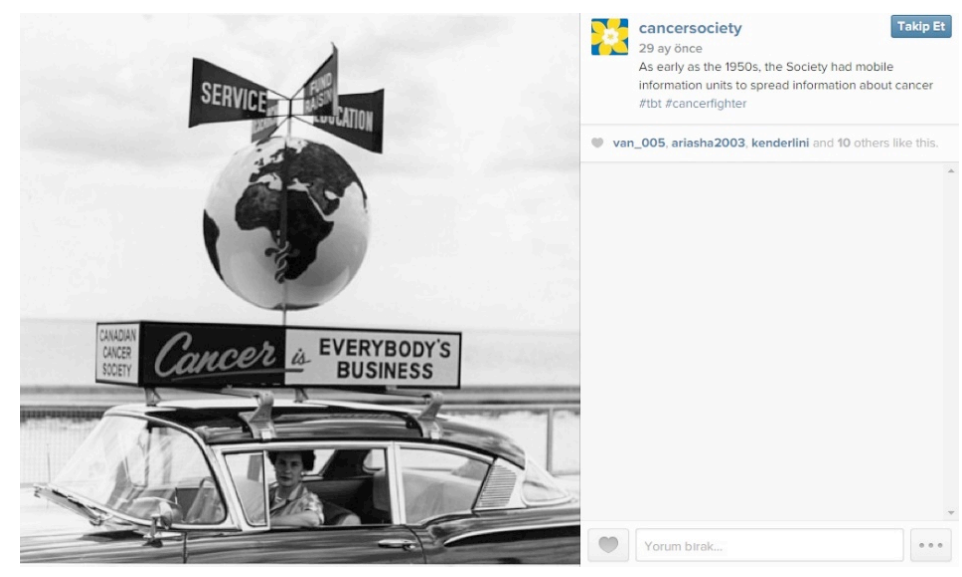

Visual 2: 3rd January 2013 Dated Visual Post

The audience is dragged into the depths of the story by the storyteller. Storytellers are introduced by going to the roots of the story. Spaces that are created by the storyteller's heroes in different times and places appeared in many different posts repeatedly. For example, they sometimes appear as a public relations campaign or sometimes demonstration march. The main point is that the storyteller is stretching the borders of place, memory and space with their involvement in the story.

Visual Post: A woman's activities like that of Canadian Cancer Society with communication devices of 1950s.

\section{Literary Post:}

In 25 February 2013 dated post;

Rituals: Posts that are created by storytellers who appear in time to create their own ritual.

17 January 2013, 25 February 2013, 28 February 2013, 5 March 2013, 11 March 2013, 14 March 2013, 21 March 2013, 22 March 2013, 28 March 2013, 28 March 2013, 4 April 2013, 25 April 2013, 9 May 2013, 27 June 2013, 1 December 2013, 30 December 2013, 16 January 2014, 2 April 2014, 6 April 2014, 6 May 2014, 9 July 2014, 9 August 2014, 25 August 2014, 16 September 2014, 24 September 2014, 2 November 2014, 16 December 2014, 26 March 2015, 2 April 2015, 15 May 2015

Hero: Storytellers in the posts

Evocations over Audience and Values: Flow of communication, continuity of the corporate culture, commitment to the corporation, sharing the future, being a member of the Canadian Cancer Society, creativity, fidelity, having a corporate structure that is recognized by the world, struggle of the heroes, corporation's versatile communication strategies.

Place/ Space/ Memory: Place is internet, space is 1950s in the Instagram world, memory is recollection transportation between past and present. 


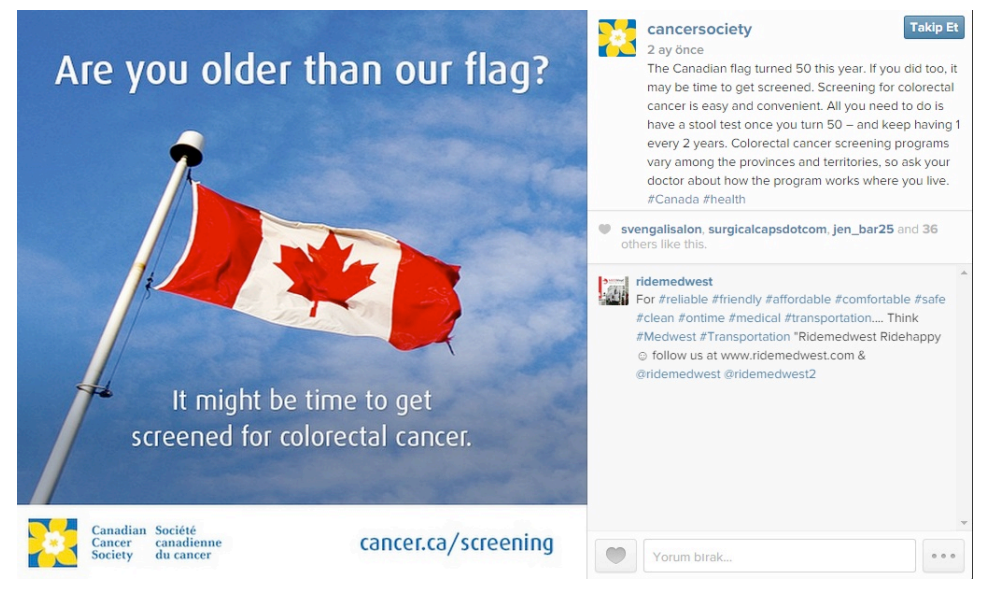

Visual 3: 6th March 2015 Dated Post

The storyteller draws attention to the issue by asking questions of the audience with the literary post on the photo of Canadian Flag. Hereby, a multi-layered structure is created by using story elements that can make evocations in memories.

Visual Post: Canadian Flag, corporate logo and writings with messages

Literary Post: Are you older than our Flag? It might be time to get screened for colorectal cancer.

Rituals: Posts related to rituals that are about being a Canadian and being proud of being a Canadian.

1 July 2013, 1 July 2014

Evocations over Audience and Values: Being Canadian, winning Canadian's heart with national emotions, nationalism, instutionalization with use of logo of the corporation, being recognized in the world, becoming an international symbol.

Place/ Space/ Memory: Place is internet, space is Instagram world, memory is factors about corporate and national identity.

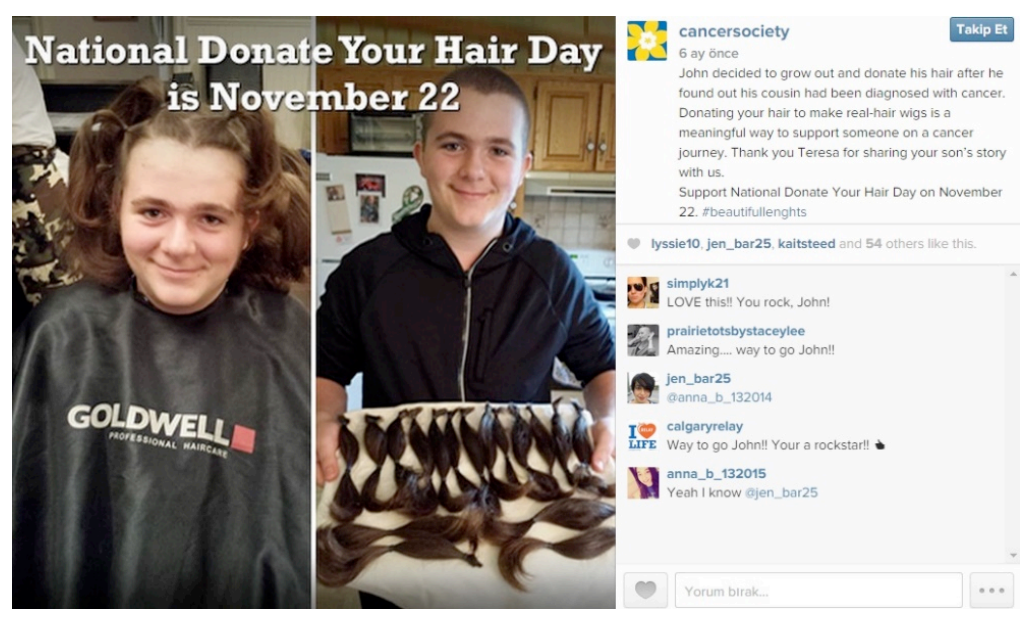

Visual 4: 16th November 2014 Dated Post

The storyteller makes transportations about situations of the Canadian Cancer Society's heroes and individuals in the story with both visual and literary posts. This transportation tells about the activities of volunteers' donation of their hair and having financial support within the framework of the agreement between the corporation and Pantene. 
Visual Post: A supporter who donates her hair and posts that tell her happiness after donation.

Rituals: Cutting the hair, posts about volunteering rituals.

17 January 2013 (cops who cut their hair), 12 June 2013 (Hair donation of an executive of the corporation), 19 October 2013 (Hair donation of a man who grows his hair for three years), 8 February 2014 (Hair donation of cops whose number is over 120), 6 November 2014 (Hair donation of a woman), 8 November 2014 (A woman who donates her hair with literary narratives), 20 November 2014 (A woman who donates her hair and posts that encourage everyone to tag their donated hair), 22 November 2014 (A woman who donates her hair and contributions of this donation to the corporation and a corporate gratitude), 22 November 2014 (A woman who donates her hair), 14 February 2015 (hair donation rituals on different platforms).

Evocations over Audience and Values: Volunteering, sacrifice, being a hero, becoming a symbol, being a part of the ritual, commitment to corporation, devotion, commitment to past, continuity of the values, being open to new ideas, transferring traditions to future with new generation (new volunteers and heroes).

Place/ Space/ Memory: Place is internet, space is Instagram world and living spaces of Instagram society, memory is individual recollections and connotations which will create social memory.

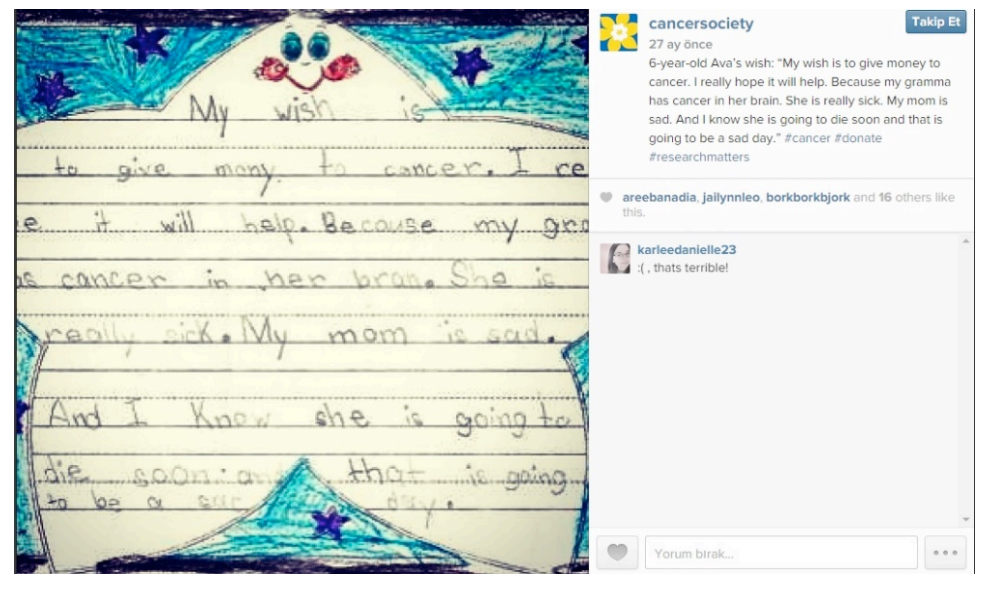

Visual 5: 11 th March 2013 Dated Post

The storyteller is creating processes that will make an emotional exchange between the story and the audience. The storyteller brings the story into daily life by handling the events with a childish perspective. He is trying to create a new place that will take a part in people's memory. Hereby, Instagram which is a tool for storytelling, refers to cultural codes by using a very old communication tool like letters.

Visual Post: A photo of a letter that is written by a six-year-old kid, and the post that shows comments and likes to this letter.

Literary Post: "Six-year-old Ava's wish; My wish is to give money to cancer. Because my grandmother has cancer in her brain. I really hope this to help her. She is really sick. My mom is sad. And I know that my grandmother is going to die soon and she, she will be so sad."

Rituals: Storyteller enabled audience to be the hero or communicate directly with the storyteller by sometimes allowing individuals' stories. Thus, this created a ritual in the narrative.

19 September 2013 (Post that tells the story of mom and her child), 16 September 2013 (A father who fights cancer with the support of his family and his family's narrative), 28 August 2013 (A person who 
died of cervical cancer and posts about her family), 14 February 2014 (Jennifier and Philippe's posts that dreams can come true.)

Heroes: Canadian Cancer Society and Society Members

Evocations over Audience and Values: Fighting, achieving, not to surrender, hope, corporate support, humanitarian values, values about existence, struggle for life, telling true stories, relating real world with story world, integration of cultural codes, recognition of non-governmental organization by having an influence over life, being a part of society, linking the story with society.

Place/ Space/ Memory: Place is internet, space is Instagram world and dimensions about posts, memory is individual recollections and connotations which will create social memory.

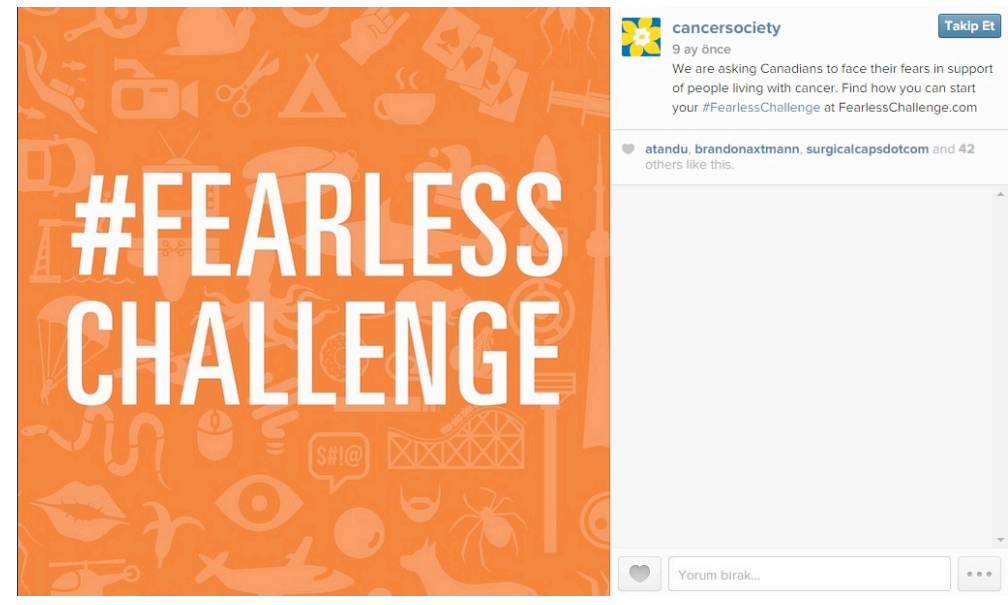

Visual 6: 7th August 2014 Dated Post

Storyteller transfers the place of the story to a different time and dimension with this narrative. Storyteller links the basic theme of the story which is "not to be afraid of cancer" with fears that are in the minds of the audience. They move people to a new dimension that both provides the chance to overcome their fears and contributes to sustainability of the story. Audience leaves the place of the storyteller, namely Instagram, and becomes a part of the whole by creating their own stories, and storyteller both creates rituals and makes people hero by transferring narratives, which are created in this different time and place, back to Instagram. Thus, Instagram causes the creation of a chronic communication network in the memories of the audience.

Visual Post: A post that appears with the "fearless challenge"

Literary Post: "We are asking Canadians to face their fears in support of people living with cancer. Find how you can start from here..."

Rituals: Posts that are shared with the call of the storyteller, and that belong to those who challenge fearlessly.

9 August 2014 (Story of jonnkanyon), 10 August 2014 (Suzya challenges her beloved hair against the donation of \$2000), 11 August 2014 (Mike Bradwell gathered \$2500 donation by walking on the CN tower), 12 August 2014 (Natalie Brown challenges water and swimming) 14 August 2014 (Farah Ismail becomes a part of the story by eating hot pepper), 15 August 2014 (A supporter/hero who challenged by promising to shave his beard), 18 August 2014 (A hero who challenges to swim with sharks).

This ritual has continued in many posts. 
Evocations over Audience and Values: Being a hero, being a part of the story, mix of stories and realities, people/memories that are transferred to the imaginary world, evaluation of feedback that comes from the audience by the storyteller and his integration of them into the story, story possessing a new place, time and space.

Place/ Space/ Memory: Place is internet, space is shifting a new web page with Instagram world and dimensions about posts, memory is individual recollections which will create social memory, and facing with witnesses.

\section{CONCLUSION}

People's life-style is changing and developing with the development of communication technologies. Through this, new social and cultural elements appear. The concept of story that includes cultural codes, and the concept of gossip, has become indistinguishable in digital platforms. Therefore, people have gradually become oblivious, with everyone on the internet beginning to act like they have Alzheimer's. The process of digital narratives becoming a digital story that bears cultural codes, rather than a gossip, is analyzed in this study. In order to do so, social lives and posts are analyzed in the study location (Instagram) like an ethnologist in this process.

In this study, Instagram is considered as a storytelling tool. It is seen that the page is used as a storytelling tool when the official page of the Canadian Cancer Society is analyzed. Symbols, rituals, heroes and values are analyzed with the stories that are presented by means of visual posts, and their process of influence on attitudes and behaviours is observed by evaluating their effect on the audience. As a consequence of this, it is seen that Instagram narratives add values, not only to individuals, but also to corporations. Within the context of developing corporate communication, it is seen that they contribute to many public relations steps like institutionalization, branding and corporate reputation.

The changeability of concepts like time, place and space are revealed within Instagram narratives. It is also revealed that transmedia applications can easily be realized in Instagram with especially people dragging themselves to another dimension by inviting each other to a "fearless challenge", and reusing the outputs from these dimensions on Instagram. A new socialisation process has begun, and the memory of the Instagram is created with the sharings on Instagram. As Huyssen says, current future started to create current past with the structure of this memory that compresses sharing speed on Instagram and memories' time and place. Instagram is a chain of visual narrative/story. Thus, when it is used professionally by a storyteller, a sustainable story will appear. Like the change and development of the prototype stories which create all the stories in the world, this will cause the creation of new prototypes for the stories of future.

\section{REFERENCES}

Alver, K. (2010). Siteril hayatlar. Ankara: Hece Publishing.

Armstrong , S. (2003). The power of storytelling in education. S. Armstrong (Ed.), Snapshots! Educational insights from the Thornburg Center. The Thornburg Center: Lake Barrington, Illinois. Assmann, J. (2001). Kültürel Bellek. İstanbul: Ayrintı Publishing.

Benjamin, B. (2006). The case study: storytelling in the industrial age and beyond. On the Horizon, 14(4), 159-164.

Bilgin, N. (2006). Sosyal bilimlerde içerik analizi: Teknikler ve örnek çalışmalar, (2 th edition), Ankara: Siyasal Kitabevi.

Çetin, G. (1996). Patrick Modiano'nun Illk Dönem Yapıtlarında Zaman ve Uzam, (Unpublished Master Thesis), Ankara University, Batı Dilleri ve Edebiyatı Anabilim Dalı.

Chatman, S. (2008). Öykü ve Söylem Filmde ve Kurmacada Anlatı Yapıs. Translated by Özgür Yaren. Ankara: De ki Publishing.

Conrad, K. S. (2013). Documenting local history: a case study in digital storytelling. Library Review, 62(8/9), 459-471.

David A. Gilliam, A.D. (2011). Storytelling By the Sales Force and its Effects on Personal Sellings and Buyer-Seller RelationShips, (Unpublished Doctoral Thesis). Oklahoma State University.

Descartes, R. (1997). Felsefenin Illkeleri. Translated by Mesut Akin, (5th edition), Istanbul: Say Publishing. 
The Turkish Online Journal of Design, Art and Communication - TOJDAC January 2017 Volume 7 Issue 1

Figa, E. (2004). The virtualization of stories and storytelling. Storytelling Magazine, 16(2), 34-36.

Gabriel, Y. (2000). Storytelling In Organizations, New York, Oxford University Press.

Gerrig, R. J. (1993). Experiencing narrative worlds: On the psychological activities of reading. Yale University Press.

Green, M. C., \& Clark, J. L. (2013). Transportation into narrative worlds: implications for entertainment media influences on tobacco use. Addiction,108(3), 477-484.

Güvenç, B. (2005). Insan ve Kültür. (11th edition). Ankara :Remzi Kitabevi.

Haven, K. (2007). Story proof: The science behind the startling power of story. Greenwood Publishing Group:USA

Huyssen, A. (2003). Present pasts: Urban palimpsests and the politics of memory. Stanford University Press.

İnceelli, A. (2005). Dijital Hikaye Anlatımının Biçimleri. Turkish Online Journal of Educational Technology, Vol.4 Issu.3 Article.18, s.134-140.

Jann, M. (2012) Anlatıbilim. Translated by Bahar Dervişcemaloğlu. İstanbul:Dergah Publishing.

Jenkins, H., http://henryjenkins.org/2009/12/the_revenge_of_the_origami_uni.html 18.12.2014

Karaman, K. (2010). Ritüellerin Toplumsal Etkileri. Süleyman Demirel Üniversitesi Fen-Edebiyat Fakültesi Sosyal Bilimler Dergisi, 2010(21).229-235

Kılanç, R. Ö. (2013). Marka Öykülemelerinin Internette Kültürel Değerler Çerçevesinde Yansimalart. The Turkish Online Journal of Design Art and Communication, 3(2).

Kıran, Z. \& Kıran, A. (2007). Yazınsal Okuma Süreçleri, (3th edition), Ankara: Seçkin Publishing.

Koca, S.K. (2010). Genel Hatları ile Kültür ve Sembol İlişkisi, SAÜ Fen Edebiyat Dergisi, 2010(2). 87-94

Kongar, E. (1999). Kültür Üzerine. (6th edition), İstanbul: Remzi Kitabevi.

Luecke, R. (2007). Güç, Etki ve İkna, Translated by Turan Parlak, Istanbul: Türkiye Işs Bankası Kültür Publishing.

Maxwell R. \& Dickman, R. (2008). İkna Yöntemleri, İstanbul: Alfa Publishing.

Moore, J. D. (2000). Visions of culture: an introduction to anthropological theories and theorists. Rowman Altamira.

Onega, S., Angel, J., \& Landa, G. (2002). Anlatıbilime Giriş. Translated by Y. Salman\&D. Hakyemez. Istanbul: Adam Publishing.

Ong, J.W. (2013). Sözlü ve Yazılı Kültür. (4 th edition). İstanbul: Metis Publishing.

Ricceur, P. (2007). Zaman ve Anlatt: Bir. Translated by Mehmet Rlfat-Sema Rlfat. Istanbul: Yapı Kredi Publishing.

Robin, B. R. (2008). Digital storytelling: A powerful technology tool for the 21st century classroom. Theory into practice, 47(3), 220-228.

Robins, K. (1997). İmaj Görmenin Kültür ve Politikasl, Translated by Nurçay Türkoğlu, İstanbul: Ayrintı Publishing.

Sancar, M. (2010). Geçmişle Hesaplaşma: Unutma Kültüründen Hatırlama Kültürüne. İstanbul: Iletişim Publishing.

Sanders, B. (1999). Öküzün A'st-Elektronik Çağda Yazılı Kültürün Çöküşü ve Şiddetin Yükselişi, Translated by Tahir Şehnaz, (2 th edition). Ankara: Ayrıntı Publishing.

Simmons, A. (2012). Etkileme ve İkna Sanatında Hikayenin Gücü. (2th edition) Translated by Gökçesu Tamer. Istanbul: Medicat Publishing.

Varnalı, K. (2013). Dijital Kabilelerin İzinde: Sosyal Medyada Netnografik Araştırmalar. İstanbul: Mediacat yayinlart.

Vaynerchuk, G. (2013). Jab, Jab, Jab, Right Hook/ How to Tell Your Story In A Noisy Social World. Harper Collins.

www.tdk.gov.tr, 19.04.2015

http://www.tdk.gov.tr/index.php?option $=$ com_gts\&arama $=$ gts\&guid $=$ TDK.GTS.558dcd0c8f8bc8.063 $64924,15.05 .2015$ 